\title{
Characterization of phenol-degrading fungi isolated from industrial waste water in Malaysia
}

\author{
Nadila Hanafee , Nor 'Azzah Mohd Salleha, Siti Aqlima Ahmad', Wan Zuhainis Saadª, Mohd \\ Termizi Yusof ${ }^{*}$ \\ ${ }^{a}$ Department of Microbiology, Faculty of Biotechnology and Biomolecular Sciences, Universiti Putra Malaysia, 43400 UPM Serdang, Selangor, \\ Malaysia \\ ${ }^{b}$ Department of Biochemistry, Faculty of Biotechnology and Biomolecular Sciences, Universiti Putra Malaysia, 43400 UPM Serdang, Selangor, \\ Malaysia
}

Received 27th November 2018 / Accepted 21st February 2019

\begin{abstract}
Microorganisms have the ability to degrade phenol. However, in Malaysia, there are lack of study on indigenous microorganisms (fungi) that have the ability to degrade phenol. A total of 141 phenoldegrading fungi isolates were isolated from soil and water samples collected from various industrial areas located in Malaysia. The fungi isolate N12 P6C3 was chosen based on its high efficiency in degrading phenol. The fungi isolate N12 P6C3 isolated from a heavy metal factory, Dungun, Terengganu was able to degrade $700 \mathrm{mg} / \mathrm{L}$ of phenol within 6 days and the mycelium growth had increased to $0.25 \mathrm{~g}$. The phylogenetic tree based on the ITS sequence analysis confirmed that the fungal identity was closely related to Penicillium janthinellum strain ATCC 4845. The optimum conditions of this fungus to degrade phenol was attained at temperature of $35^{\circ} \mathrm{C}$, ammonium sulphate at $3 \mathrm{~g} / \mathrm{L}, 0.05 \mathrm{~g} / \mathrm{L}$ of sodium chloride, and $\mathrm{pH}$ 6. The ability of P. janthinellum strain N12 P6C3 in the degradation of phenol may provide additional knowledge on locally isolated phenol-degrading fungi which could contribute towards phenol waste management in Malaysia.
\end{abstract}

Keywords: biodegradation, fungi, phenol

\section{INTRODUCTION}

Environmental pollution is one of the critical problems the world is facing today. Rapid industrial growth, urbanization, as well as increasing of hazardous and toxic waste discharged, eventually leads to the increasing of xenobiotic levels in the environment (Gami et al., 2014; Javed and Usmani, 2015). Based on reports by Agency for Toxic Substances and Disease Registry, phenol is one of the major industrial chemicals found in waste effluent which can be present in the environment through natural or chemical processes (ATSDR, 2008).
Phenol is an aromatic compound that is widely distributed as environmental pollutants due to their existence in the waste effluents of many industrial processes including petroleum refineries, pharmaceuticals, paper manufacture, textiles, plastics, dyes, and phenolic resin industries (Santos and Linardi, 2004; Leitão, 2009; Wang et al., 2010). Phenols can also naturally present in decomposition of organic materials or in coal (Basha et al., 2010). Excessive level of phenolic compounds in the environment leads to phenol's accumulation, affecting groundwater and

*Author for correspondence: Mohd Termizi Yusof, Department of Microbiology, Faculty of Biotechnology and Biomolecular Sciences, Universiti Putra Malaysia, 43400 UPM Serdang, Selangor, Malaysia. Email mohdtermizi@upm.edu.my 
soil quality (Michalowicz and Duda, 2007; Panagos et al., 2013).

Distributions of phenol provide a great impact to the environment and human beings. Even at low concentrations, phenol can be toxic and lethal to aquatic organisms (Rittmann and McCarty, 2001). Phenol is rapidly absorbed by human body through inhalation, ingestion, and dermal contact (HPA, 2007). Exposure to phenol can cause irritation to the eye, severe skin damage, serious gastrointestinal damage, cardiovascular disease, and even death (ATSDR, 2008). Therefore, priority and great concern have been placed in these issues, toward the exposure of phenol and the removal of phenol effluent from the ecosystems (Barlow et al., 2007).

Various treatment techniques have been developed for phenol removal including chemical, biological, and physical methods. Solvent extraction, chemical oxidation, adsorption, and incineration have been widely applied, but all these methods are very costly and most probably will produce hazardous by products (Basha et al., 2010; Bui et al., 2012; Thappu et al., 2012). This is why biological approach, biodegradation is preferred to degrade phenol since it is environmentally friendly and cost effective (Wang et al., 2010).

A number of microorganisms including bacteria and fungi have the ability to utilize phenol as their carbon source for growth (Chen et al., 2006). Most of the phenol-degrading microorganisms reported were bacteria including Acinetobacter spp., Pseudomonas spp., Bacillus spp., and Rhodococcus spp. (Ahmad et al., 2011; Sridevi et al., 2011; Mahiuddin et al., 2012; Aravindhan et al., 2014; Hasan and Jabeen, 2015). Besides bacteria, fungi also have been reported as phenol degrader. Some of examples are Aspergillus fumigatus, Fusarium flociferum, Aspergillus awamori, Penicillium chrysogenum, Trichosporium cutaneum, and Candida tropicalis (Mendonça et al., 2004; Stoilova et al., 2006; Leitão et al., 2007; Tuah et al., 2009; Ravikumar et al., 2011).

Phenol-degrading microorganisms may utilize phenol in two pathways either through aerobic or anaerobic pathway (Haiyin et al., 2007; Tuah et al., 2009; Sarwade and Gawai, 2014). The absence or presence of oxygen is very important in determining the fate of phenol biodegradation pathway (Sridevi et al., 2012). In aerobic condition, oxygen is used by the enzyme phenol hydroxylase to produce catechol. Depending on the microorganisms involved, the resulting catechol can be degraded into two pathways either ortho or meta pathway. In the ortho pathway, the enzyme catechol 1,2-dioxygenase transforms catechol to cis, cis muconate whereas in the meta pathway, the enzyme catechol 2, 3-dioxygenase convert catechol to 2-hydroxymuconic semialdehyde (van Schie and Young, 2000; Tuah et al., 2009; Supriya and Neehar, 2014). The products for both pathways are further incorporated into the Krebs cycle (Soudi and Kolahchi, 2011).

In contrast to bacteria, fungi are able to adapt easily to the ecosystem and able to grow at extreme condition (Atagana, 2004; Stoilova et al., 2008). However, in Malaysia, the investigation on phenol-degrading fungi is poorly reported. Therefore, this study was conducted to provide preliminary information on phenol-degrading fungi in Malaysia.

\section{MATERIALS AND METHODS}

\section{Isolation and screening of phenol-degrading} fungi. Water and soil samples were collected from various industrial areas located in Selangor, Kedah and Terengganu, Malaysia. The water and soil samples were collected from $10-20 \mathrm{~cm}$ from the soil and water surface. Aseptically the samples were transferred into sterile polypropylene tubes and stored at $4^{\circ} \mathrm{C}$. The samples were diluted in 10 $\mathrm{mL}$ of sterile distilled water and were grown in Liquid Mineral Salt medium (LMS); made up of $0.5 \mathrm{~g} \mathrm{MgSO}_{4} .7 \mathrm{H}_{2} \mathrm{O}, 11.8 \mathrm{~g} \mathrm{KH}_{2} \mathrm{PO}_{4}, 2.3 \mathrm{~g}$ $\mathrm{K}_{2} \mathrm{HPO}_{4}, 0.05 \mathrm{~g} \mathrm{CuSO}_{4}, 0.05 \mathrm{~g} \mathrm{NaCl}, 0.25 \mathrm{~g}$ $\mathrm{NH}_{4} \mathrm{Cl}, 0.01 \mathrm{~g} \mathrm{MnSO}_{4}, 0.1 \mathrm{~g} \mathrm{FeSO}_{4}$, and $0.01 \mathrm{~g}$ $\mathrm{ZnSO}_{4}$ (Cai et al., 2007). All the chemicals were dissolved in distilled water, $\mathrm{pH}$ to 6 and brought up to $1 \mathrm{~L}$. Appropriate amount of phenol and 100 $\mu \mathrm{g} / \mathrm{mL}$ of penicillin-streptomycin antibiotic were added to the autoclave's medium prior to inoculation. The cultures were incubated at room temperature for 3 days.

Sensitivity of phenol-degrading fungi. The ability of each isolate to utilize phenol was tested at different phenol concentrations. Concentration 
of phenol was gradually increased from $(\mathrm{mg} / \mathrm{L})$ $100,300,500$, and up to 700 . Mycelium of the isolate was homogenized and incubated into Potato Dextrose Broth (PDB) for $24 \mathrm{~h}$ at $125 \mathrm{rpm}$ under room temperature. After $24 \mathrm{~h}, 0.1 \mathrm{~g}$ of fungal mycelium was harvested and incubated into $50 \mathrm{~mL}$ LMS solution supplemented with various concentrations of phenol at $125 \mathrm{rpm}$ under room temperature. All samples were periodically taken for dry weight measurement and phenol degradation rate analysis. Mycelia from LMS media were filtered and washed with sterile distilled water for several times. Mycelia obtained were then kept in a small pack of aluminium foil and dried at $60^{\circ} \mathrm{C}$. The dry weight of the mycelia was measured by subtracting the initial weight of mycelia and aluminium foil. 4amino antipyrine colorimetric method was used for phenol degradation rate analysis (APHA, 1998). All experiments were carried out in three replicates.

Identification of phenol-degrading fungi. DNA extraction was done as described by Raeder and Broda with some modification (Raeder and Broda, 1985). The extracted genomic DNA was amplified using Internal Transcribed Spacer (ITS) primers, ITS1 (5'-TCCGTAGGTGAACCTGCG G-3') and ITS4 (5'-TCCTCCGCTTATTGATAT GC-3') (White et al., 1990; Pryce et al., 2006). The PCR reaction mixture consisted of $25 \mu \mathrm{L}$ of $2 \mathrm{X}$ Taq master mix (Vivantis Technologies), $19 \mu \mathrm{L}$ of free nuclease water, $2 \mu \mathrm{L}$ of $0.5 \mu \mathrm{M}$ of each primer, and $2 \mu \mathrm{L}$ of DNA template. The reaction was performed in a thermal cycler under the following temperature: denaturation at $94^{\circ} \mathrm{C}$ for 2 min, 30 cycles of denaturation at $94^{\circ} \mathrm{C}$ for $1 \mathrm{~min}$, annealing at $49^{\circ} \mathrm{C}$ for $30 \mathrm{~s}$, and primer extension at $72^{\circ} \mathrm{C}$ for $25 \mathrm{~s}$, with the penultimate step of $72^{\circ} \mathrm{C}$ for $10 \mathrm{~s}$ and lastly cooling at $4^{\circ} \mathrm{C}$. DNA sequence was analyzed using Basic Local Alignment Search Tool (BLAST) (www.ncbi.nlm.gov). The sequence was aligned using CLUSTAL W in Molecular Evolutionary Genetics Analysis version 6 (MEGA6). Phylogenetic tree was constructed using Neighbour-Joining method with bootstrap value replication of 1000 .

\footnotetext{
Fungal growth and phenol degradation activity of the selected isolates. To study the physiological factors affecting the growth and
}

phenol degradation of the selected isolate, different temperature $(10,15,20,25,30,35,40$, 45,50 , and $55^{\circ} \mathrm{C}$ ), nitrogen source (ammonium nitrate, ammonium sulphate, ammonium chloride, sodium nitrate, serine, isoleucine, valine, and phenylalanine), concentration of nitrogen source $(0,0.25,0.5,1,2,3,4$, and $5 \mathrm{~g} / \mathrm{L})$, sodium chloride $(0,0.05,0.1,0.2,0.3,0.4,0.6,0.8$, and 1 $\mathrm{g} / \mathrm{L})$ and $\mathrm{pH}$ range of $4.0-9.0$ were investigated. Fungal isolate $(0.1 \mathrm{~g})$ was inoculated in $50 \mathrm{~mL}$ LMS and incubated on an orbital shaker at 125 rpm for 2 days. The degradation of phenol was detected using 4-AAP colorimetric method and the fungal growth was measured by measuring the dry weight of the mycelium.

Statistical analysis. All data obtained were subjected to statistical analysis. The SPSS 17.0 software was used for the analysis. Comparison among the groups was performed using one-way analysis of variance (ANOVA) with post hoc analysis by Tukey's test (Haynes, 2013).

\section{RESULTS AND DISCUSSION}

\section{Isolation and screening for phenol-degrading} fungi. A total of 141 phenol-degrading fungi were isolated from soil and water samples collected from various industrial areas located in Malaysia. Most samples were obtained from charcoal factories, heavy metal waste sites, drains, sludges, agricultural sites, and oil contaminated areas. Sixteen fungal isolates were selected for further investigation based on their ability to degrade phenol (Table 1). All isolates were grown on LMS agar plate supplemented with phenol as the sole carbon source. All 16 isolates of phenol-degrading fungi were assessed daily for phenol degradation $(100 \mathrm{mg} / \mathrm{L}$ phenol $)$ in LMS. Among the 16 isolates, 6 isolates (N7 P1C1, N5 P2C2, N3 P2C2, DD P1C2, N12 P6C3 and N12 P4C1) were able to degrade $100 \%$ phenol within 2 days (Figure 1a). Isolate N4 P2C1 consumes phenol completely in 4 days while isolates 3 LP2, I LP1, N15 P2C1 and $\mathrm{N} 2$ P9C1 required 6 days to completely degrade $100 \mathrm{mg} / \mathrm{L}$ of phenol. Isolates ${ }^{\circ} 4 \mathrm{P} 1 \mathrm{C} 1$ and N3 P2C1 only able to degrade less than $30 \%$ of phenol at the end of incubation period (day 8). Growth rate of each fungal isolates was recorded 
(Figure 1b). The mycelia cell increased as the phenol concentration started to decrease. This proved phenol was being utilized as carbon source for cellular growth (Wang et al., 2010).
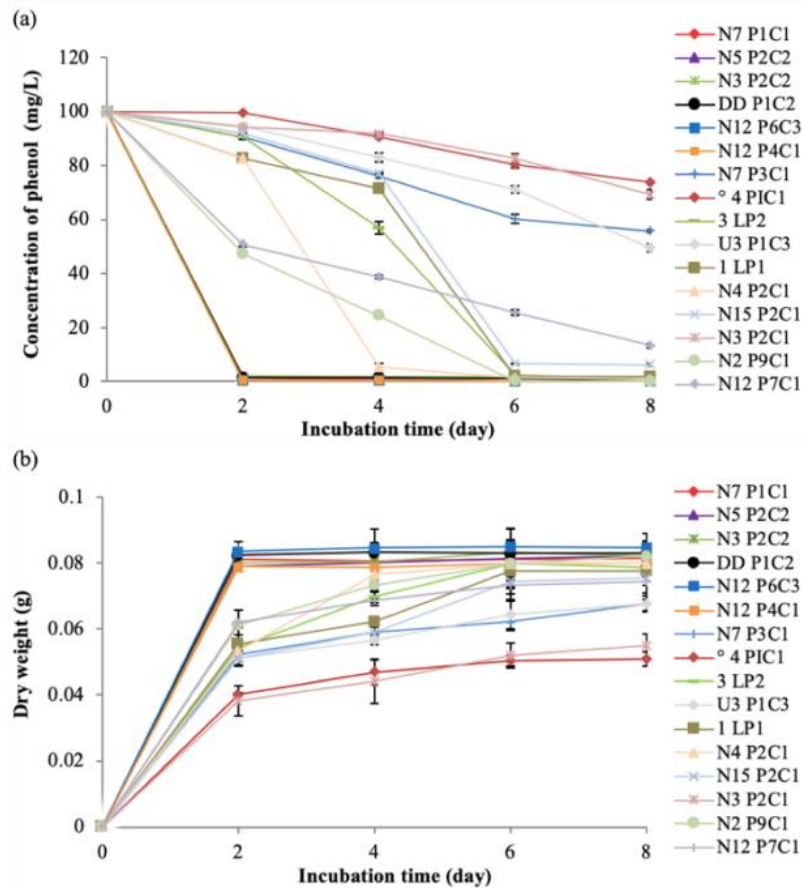

Figure 1. (a) Phenol degradation of 16 fungal isolates grown in LMS solution supplemented with $100 \mathrm{mg} / \mathrm{L}$ of phenol for 8 days at $125 \mathrm{rpm}$ under room temperature and (b) dry weight of 16 fungal isolates within 8 days. Each point represents the mean of triplicate \pm SD.

Six fungal isolates were further analyzed for phenol tolerance at different phenol concentrations $(300,500$, and $700 \mathrm{mg} / \mathrm{L})$. At 300 $\mathrm{mg} / \mathrm{L}$ of phenol, all isolates required 3 days to completely degrade the phenol except for isolate N3 P2C2 which needed 4 days (Figure 2a). While at $500 \mathrm{mg} / \mathrm{L}$ phenol, only two isolates $(\mathrm{N} 12 \mathrm{P} 6 \mathrm{C} 3$ and DD P1C2) were able to degrade $100 \%$ phenol within 4 days of incubation time (Figure 2b). As the phenol concentration increased to $700 \mathrm{mg} / \mathrm{L}$, only isolate N12 P6C3 was able to completely degrade $700 \mathrm{mg} / \mathrm{L}$ of phenol within 6 days $(p<0.05)$ compared to other isolates (Figure $2 c)$. While isolates DD P1C2 and N7 P1C1 required 7 days to completely degrade $700 \mathrm{mg} / \mathrm{L}$ of phenol. The least potent fungi were isolates N5 P2C2, N12 P4C1, and N3 P2C2 which degraded 2 - 20\% of phenol at the end of incubation time. The mycelia dry weight had increased to $0.25 \mathrm{~g}$ for 700 $\mathrm{mg} / \mathrm{L}$ of phenol concentration (Figure 3). Isolate
N12 P6C3 was further analysed due to its efficiency in degrading phenol compared to other isolates. The results show that the higher phenol concentration, the more time required to completely degrade phenol and also a longer lag phase was observed (Figure 2) (Stoilova et al., 2006; Wang et al., 2010; Supriya and Neehar, 2014).
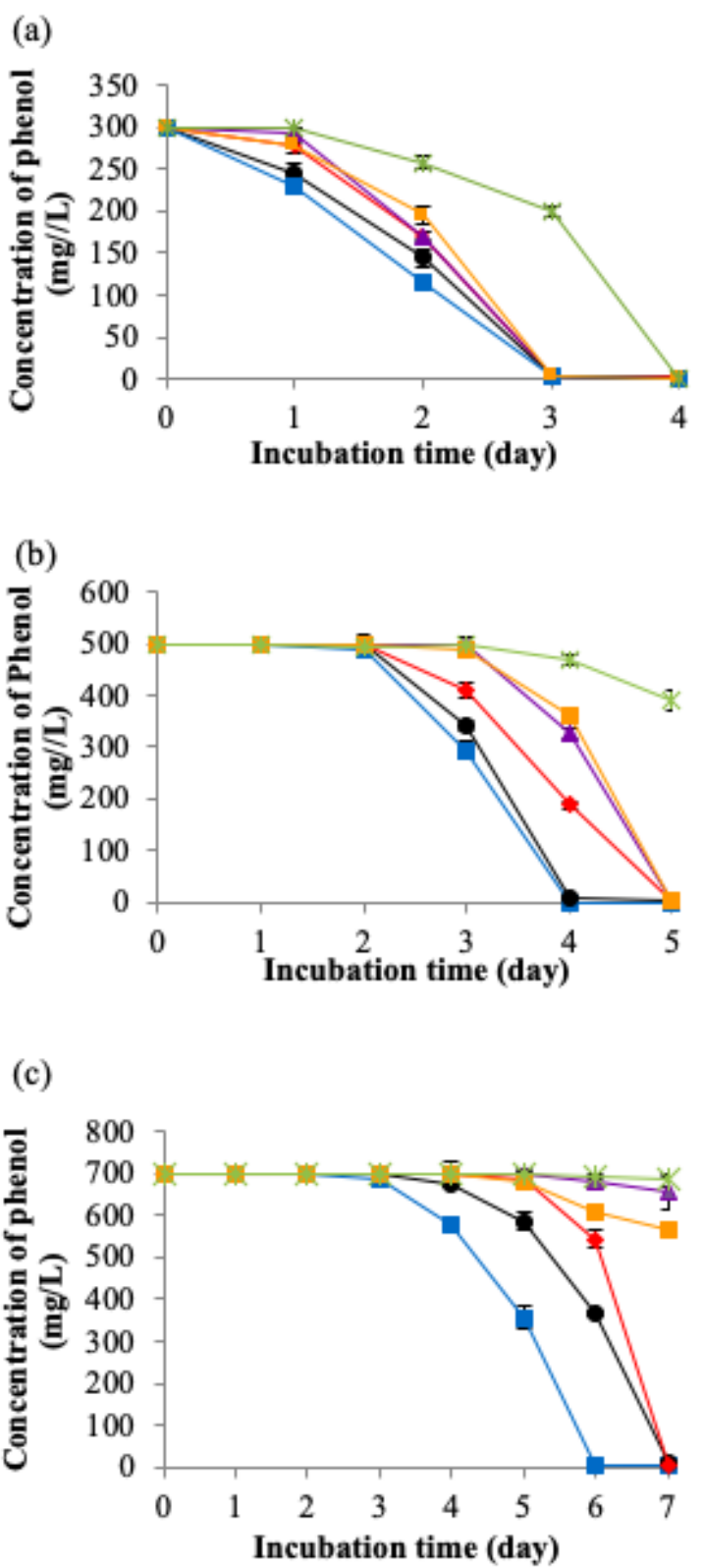

Figure 2. Phenol degradation of 6 fungal isolates: $(--)$ N12 P6C3, ( - $)$ DD P1C2, $(\rightarrow)$ N7 P1C1, (-) N5 P2C2, (-) N12 P4C1, and $(-)$ N3 P2C2 incubated in LMS supplemented with various phenol concentration: (a) $300 \mathrm{mg} / \mathrm{L}$, (b) $500 \mathrm{mg} / \mathrm{L}$ and (c) $700 \mathrm{mg} / \mathrm{L}$. Values shown are mean $\pm \mathrm{SD}, \mathrm{n}=3$. 


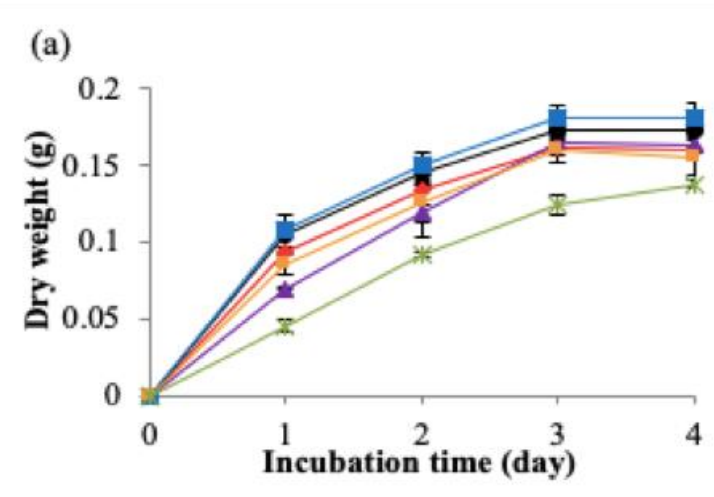

(b)

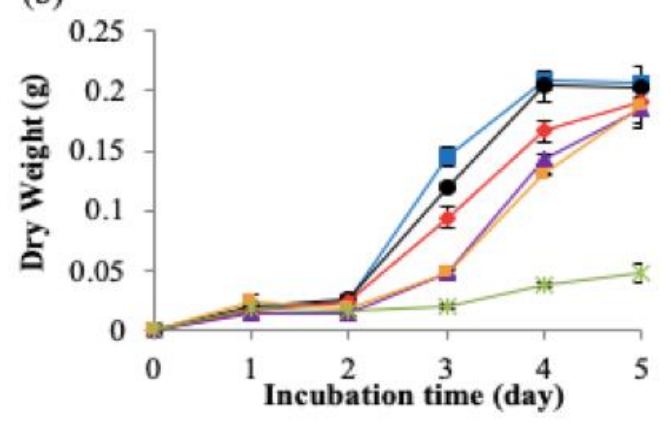

(c)

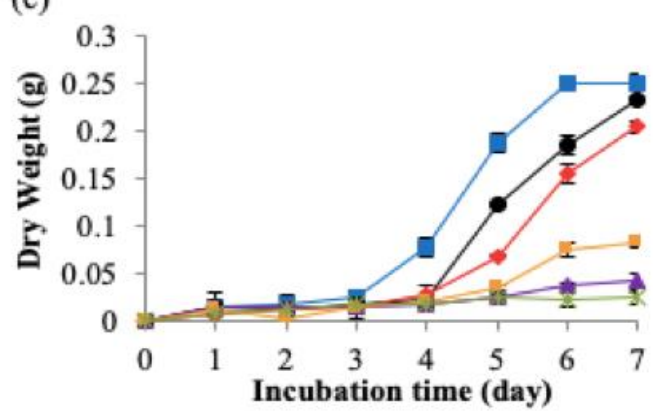

Figure 3. Dry weight of 6 fungal isolates: $(--)$

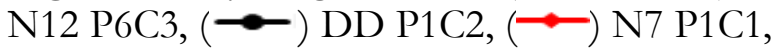
$(-)$ N5 P2C2, (- $\left.{ }^{-}\right) \mathrm{N} 12 \mathrm{P} 4 \mathrm{C} 1$, and $\left({ }^{-}\right) \mathrm{N} 3$ P2C2 incubated in LMS supplemented with various phenol concentration: (a) $300 \mathrm{mg} / \mathrm{L}$, (b) $500 \mathrm{mg} / \mathrm{L}$ and (c) $700 \mathrm{mg} / \mathrm{L}$. Values shown are the mean $\pm \mathrm{SD}, \mathrm{n}=3$.

\section{Optimization of conditions for growth and phenol degradation of Penicillium} janthinellum strain N12 P6C3. The effect of temperature on the growth of Penicillium janthinellum strain N12 P6C3 in the presence of $300 \mathrm{mg} / \mathrm{L}$ phenol was studied at different temperatures ranging from 10 to $60^{\circ} \mathrm{C}$. The mycelial growth and the phenol degradation gradually increased as the temperature increased until it reached an optimum temperature, $35^{\circ} \mathrm{C}$ $(p<0.05)$ (Figure 6). The mycelial growth and phenol degradation ability of the fungus decrease at $40^{\circ} \mathrm{C}$ and ceased at $60^{\circ} \mathrm{C}$. Supriya and Neehar (2014) reported similar observation in Aspergillus niger where the optimum temperature for the degradation of phenol was recorded at $35^{\circ} \mathrm{C}$ and the growth decreases drastically at low $\left(25^{\circ} \mathrm{C}\right)$ and high $\left(60^{\circ} \mathrm{C}\right)$ temperature. The growth and phenol degradation rate decrease at low temperature due to the delayed activity in cold conditions. While at high temperature, the enzyme responsible for phenol degradation has been denatured, thus exhibit lower growth rate (El- Naas et al., 2009).

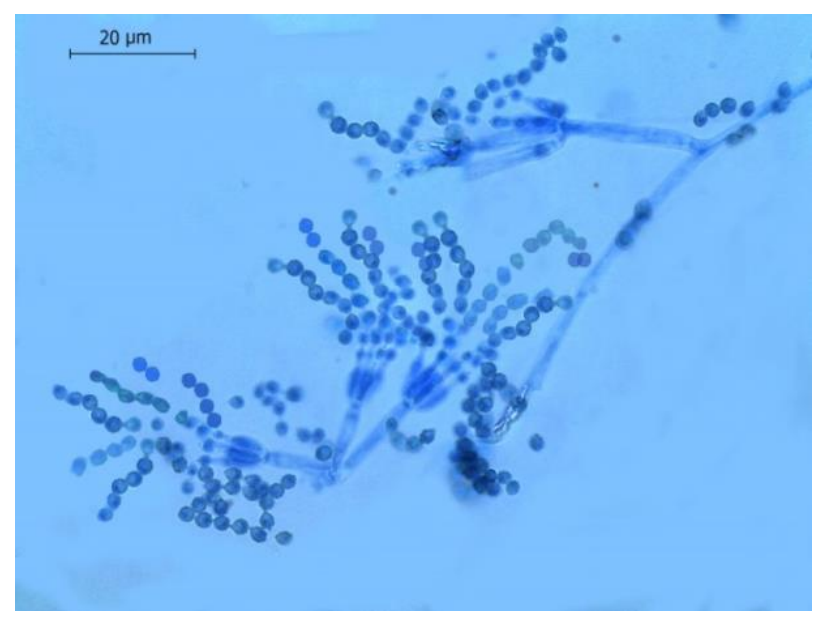

Figure 4. Microscopic image of isolate N12 P6C3 under light microscope with 1000X magnification.

Ammonium sulphate appeared to be the best nitrogen source for $P$. janthinellum strain N12 P6C3 with $73.4 \%$ phenol degradation (Figure 7a). Ammonium sulphate gave the highest phenol degradation activity and fungal growth compared to other nitrogen sources $(\mathrm{p}<0.05)$, followed by ammonium chloride and ammonium nitrate. The contribution of nitrogen sources leads to faster phenol degradation rate and increases in cell biomass. It is probable that the simultaneous metabolization of these nutrients with phenol allows the cells to overcome the inhibition effect of fungal growth caused by phenol (Neumann et al., 2004; Khleifat, 2006). Figure $7 \mathrm{~b}$ shows the effects of different concentration of ammonium sulphate ranges from $0-5 \mathrm{~g} / \mathrm{L}$ on phenol degradation and fungal growth. The optimum concentration of ammonium sulphate for the highest phenol degradation activity was recorded at $3 \mathrm{~g} / \mathrm{L}$ with $89.9 \%$ degradation $(\mathrm{p}<0.05)$. 
Table 1. Growth of fungal isolates on LMS supplemented with $100 \mathrm{mg} / \mathrm{L}$ of phenol for 3 days at room temperature.

\begin{tabular}{cccc}
\hline No & Location & Isolates & Diameter of mycelia (cm) \\
\hline 1 & Charcoal factory, Dungun, Terengganu & N7 P1C1 & $2.633 \pm 0.115^{\mathrm{e}}$ \\
2 & Charcoal factory, Dungun, Terengganu & N5 P2C2 & $2.193 \pm 0.210^{\mathrm{de}}$ \\
3 & Dungun, Terengganu & N3 P2C2 & $2.200 \pm 0.100^{\mathrm{de}}$ \\
4 & Bangi, Selangor & DD P1C2 & $2.733 \pm 0.058^{\mathrm{e}}$ \\
5 & Awie Metal, Dungun, Terengganu & N12 P6C3 & $2.667 \pm 0.208^{\mathrm{e}}$ \\
6 & Awie Metal, Dungun, Terengganu & N12 P4C1 & $2.167 \pm 0.321^{\mathrm{de}}$ \\
7 & Charcoal factory, Dungun, Terengganu & N7 P3C1 & $1.567 \pm 0.208^{\mathrm{bc}}$ \\
8 & Serdang, Selangor & '4 P1C1 & $0.867 \pm 0.208^{\mathrm{a}}$ \\
9 & Klang River & 3 LP2 & $1.533 \pm 0.153^{\mathrm{bc}}$ \\
10 & Pendang, Kedah & U3 P1C3 & $1.167 \pm 0.208^{\mathrm{ab}}$ \\
11 & Shah Alam, Selangor & N4 P2C1 & $1.200 \pm 0.200^{\mathrm{ab}}$ \\
12 & Charcoal factory, Dungun, Terengganu & N15 P2C1 & $1.667 \pm 0.153^{\mathrm{bcd}}$ \\
13 & Awie Metal, Dungun, Terengganu & N3 P2C1 & $0.933 \pm 0.231^{\mathrm{a}}$ \\
14 & Dungun, Terengganu & N2 P9C1 & $1.833 \pm 0.153^{\mathrm{cd}}$ \\
15 & Dungun, Terengganu & N12 P7C1 & $1.700 \pm 0.200^{\mathrm{bcd}}$ \\
16 & Awie Metal, Dungun Terengganu & & $1.333 \pm 0.115^{\mathrm{abc}}$ \\
\hline
\end{tabular}

Note: Values are mean of triplicate \pm standard deviation.

${ }^{a-e}$ Mean values with different superscripts are significantly different $(\mathrm{p}<0.05)$.

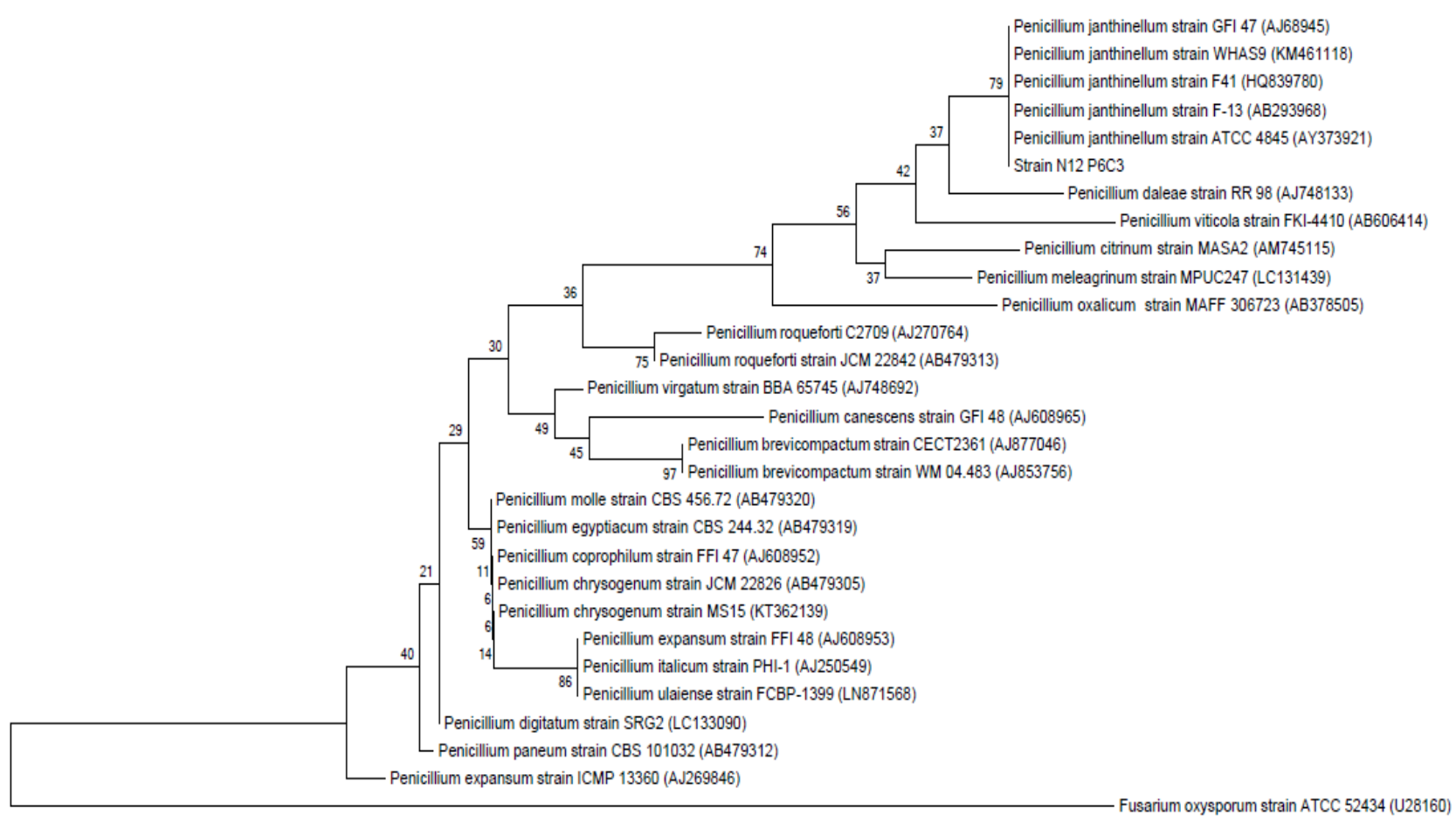

Figure 5. A phylogenetic tree (neighbor-joining method) showing genetic relationship between fungal isolate N12 P6C3 and other related reference fungi based on the ITS sequence analysis. Species name are followed by the accession numbers of their ITS region sequences. Fusarium oxysporum strain ATCC 52434 is the outgroup. 


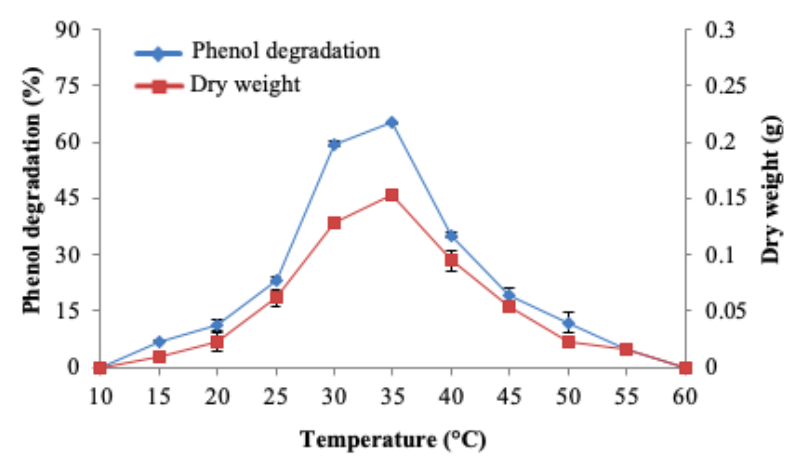

Figure 6. The effect of temperatures on the growth and phenol degradation of Penicillium janthinellum strain N12 P6C3. The isolate was grown in LMS supplemented with $300 \mathrm{mg} / \mathrm{L}$ phenol incubated in orbital shaker $(125 \mathrm{rpm})$ for 2 days. Phenol degradation rate was determined using 4-AAP assay. Data represents mean $\pm \mathrm{SD}$, $\mathrm{n}=3$.
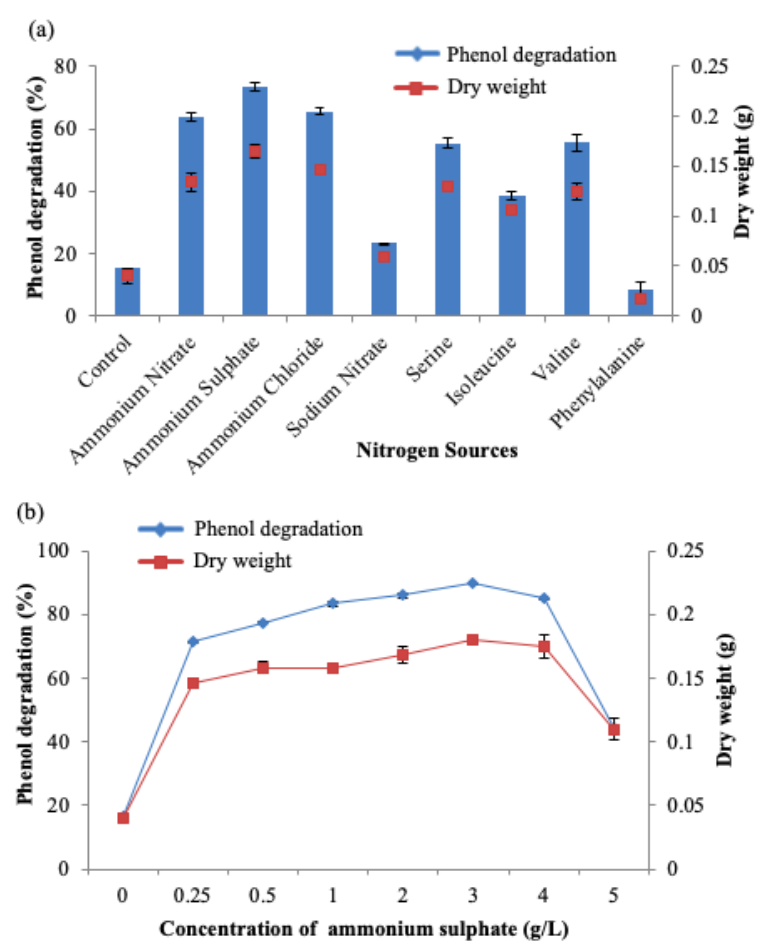

Figure 7. Phenol degradation activity and growth of Penicillium janthinellum strain N12 P6C3. (a) Phenol degradation activity and growth in various nitrogen sources; (b) phenol degradation activity and growth in various ammonium sulphate concentrations. Data represents mean $\pm S D, n=3$.

The effect of various concentration of $\mathrm{NaCl}$ on growth of strain N12 P6C3 was observed at 0 to $1 \mathrm{~g} / \mathrm{L}$ (Figure 8). The results show P. janthinellum strain N12 P6C3 grew best at $0.05 \mathrm{~g} / \mathrm{L} \mathrm{NaCl}$ and was able to degrade $88 \%$ of phenol after 2 days of incubation compared to other concentrations $(p<0.05)$. The reduction of growth and phenol degradation were recorded at high $\mathrm{NaCl}$ concentrations. This indicates $P$. janthinellum strain $\mathrm{N} 12 \mathrm{P} 6 \mathrm{C} 3$ requires low amount of $\mathrm{NaCl}$ for their optimum growth. High $\mathrm{NaCl}$ concentration could affect the degradation of phenol due to osmotic stress to the fungal growth which eventually decreases the phenol degradation rates (Annadurai et al., 2008).

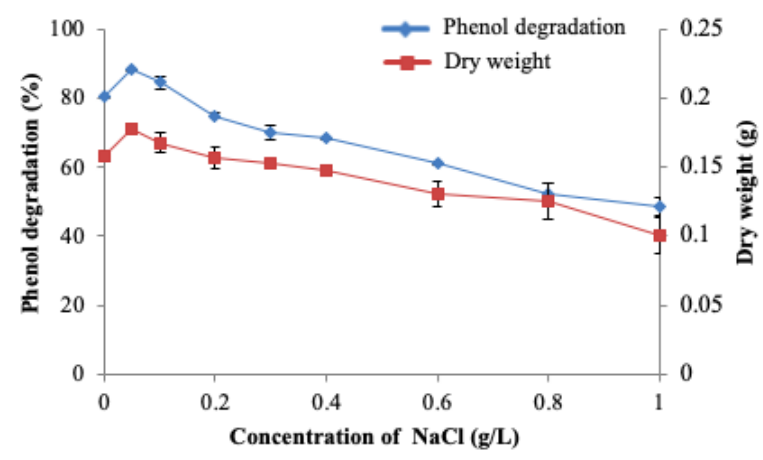

Figure 8. The effect of sodium chloride concentration on phenol degradation activity and growth of Penicillium janthinellum strain N12 P6C3. Data represents mean $\pm \mathrm{SD}, \mathrm{n}=3$.

The effect of $\mathrm{pH}$ on the growth and degradation of phenol by P. janthinellum strain N12 P6C3 was studied using an overlapping buffer system consisting of acetate, phosphate, and Tris- $\mathrm{HCl}$ buffer at the $\mathrm{pH}$ ranging from 4.0-9.0 (Ahmad et al., 2011). Overlapping buffer system was employed to cancel out the different effect of buffers on fungal growth and phenol degradation (Ahmad, 2012). The results (Figure 9) show the fungus able to grow at $\mathrm{pH}$ ranging from 5.5-6.5 $(\mathrm{p}<0.05)$ in phosphate buffer. The fungal growth increased with the increased of $\mathrm{pH}$ and peaked at $\mathrm{pH}$ 6. The highest degradation rate was achieved at $\mathrm{pH} 6$ with $88.7 \%$ phenol degradation $(\mathrm{p}<0.05)$, indicating $P$. janthinellum strain N12 P6C3 prefer slightly acidic condition. The growth of this fungus and phenol degradation rate was dramatically decreased at $\mathrm{pH}$ using acetate and Tris-HCl buffers. Extremely low or high $\mathrm{pH}$ usually leads to loss of activity for most of the microbial enzyme. Enzymes produced by microorganisms are significantly affected by the change in $\mathrm{pH}$ as it is a crucial factor in the stability of the enzyme and can affect the solubility of 
enzymatic compounds (Banerjee and Ghoshal, 2010).
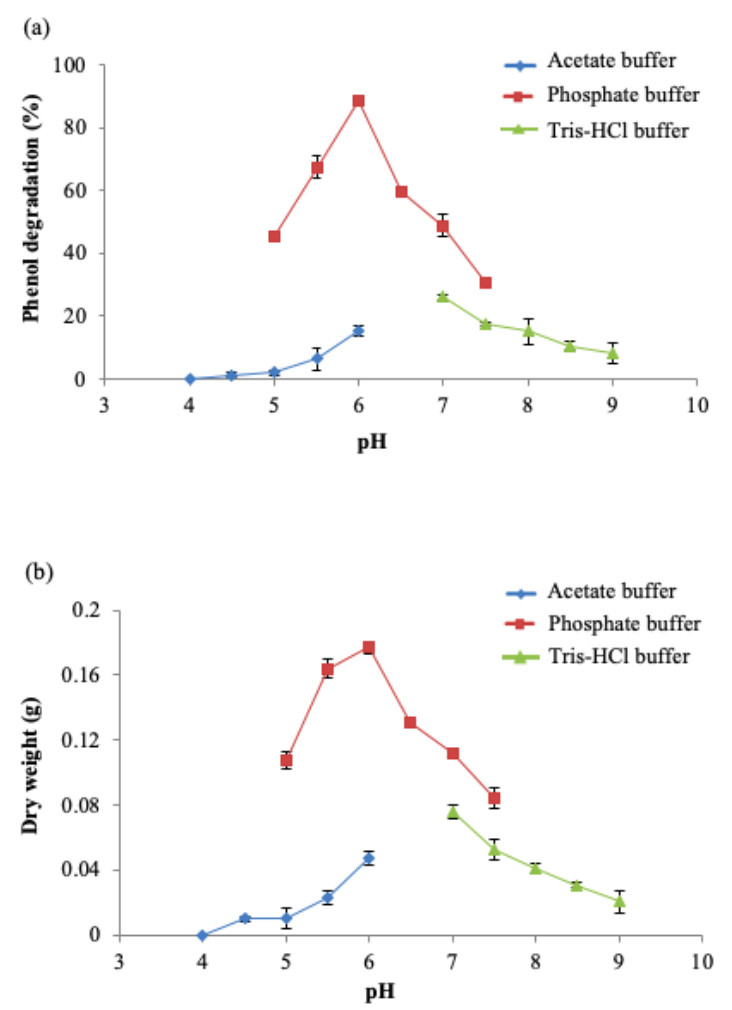

Figure 9. The effect of $\mathrm{pH}$ on phenol degradation activity and growth of Penicillium janthinellum strain N12 P6C3 using three overlapping buffers $(\bullet)$ acetate, $(-)$ phosphate and (-) tris-HCl buffers. (a) Phenol degradation activity; (b) fungal growth. Data represents mean $\pm S D, n=3$.

\section{CONCLUSION}

A total of 141 phenol-degrading fungi were isolated from phenol-contaminated sites and tested for their ability to degrade phenol. Based on the results, strains N12 P6C3 was selected as the best fungal isolate for further investigations. Strain N12 P6C3 was identified as Penicillium jantbinellum. Various parameters including temperature, nitrogen source, salinity, $\mathrm{pH}$, and phenol concentration affecting phenol degradation activity of $P$. janthinellum strain N12 P6C3 were studied. The optimum conditions for phenol degradation were achieved at temperature of $35^{\circ} \mathrm{C}$, ammonium sulphate at $3 \mathrm{~g} / \mathrm{L}, 0.05 \mathrm{~g} / \mathrm{L}$ of sodium chloride, and $\mathrm{pH} 6$ using phosphate buffer system.

\section{REFERENCES}

Agency for Toxic Substances and Disease Registry (ATSDR). 2008. Toxicological profile for phenol. Public Health Service, U.S. Department of Health and Human Services. Atlanta, GA.

Ahmad, S. A. 2012. Biodegradation of phenol by locally isolated Acinetobacter sp. strain AQ5NOL 1 and purification of phenol hydroxylase. PhD Thesis, Universiti Putra Malaysia.

Ahmad, S. A., Syed, M. A., Arif, N. M., Shukor, M. Y. A., \& Shamaan, N. A. 2011. Isolation, identification and characterization of elevated phenol degrading Acinetobacter sp. strain AQ5NOL 1. Australian Journal of Basic and Applied Sciences 5(8): 1035-1045.

American Public Health Association (APHA). 1998. Standard Methods for the Examination of Water Wastewater. 20th Edition. Method 5530. pp 540-544.

Annadurai, G., Ling, L. Y., \& Lee, J. F. 2008. Statistical optimization of medium components and growth conditions by response surface methodology to enhance phenol degradation by Pseudomonas putida. Journal of Hazardous Materials 151: 171-178.

Aravindhan, R., Naveen, N., Anang, G., Raghavarao, J., \& Unninair, B. 2014. Kinetics of biodegradation of phenol and a polyphenolic compound by a mixed culture containing Pseudomonas aeruginosa and Bacillus subtilis. Applied Ecology and Environmental Research 12(3): 615-625.

Atagana, H. I. 2004. Bioremediation of creosote-contaminted soil in South Africa by land farming. Journal of Applied Microbiology 96: 510-520.

Bandh, S. A., Kamili, A. N., Ganai, B. A., \& Saleem, S. 2011. Isolation, identification and seasonal distribution of Penicillium and Aspergillus species in Dal Lake, Kashmir. International Journal of current Research 3(10): 38-42.

Banerjee, A. \& Ghoshal, A. K. 2010. Isolation and characterization of hyper phenol tolerant Bacillus sp. from oil refinery and exploration sites. Journal of Hazardous Materials 176: 85-91.

Barlow, J., Johnson, J. A. P., Belcher, S. M., \& Fenton, S. E. 2007. Early life exposure to phenols and breast cancer risk in later years: Fact sheet on phenols. Breast Cancer and the Environment Research Centre Community Outreach and Translation Cores. pp 1-20.

Basha, K. M, Rajendran, A., \& Thangavelu, V. 2010. Recent advances in the biodegradation of phenol: A review. Asian Journal Experiment Biology Science 1(2): 21-234.

Bui, H. B., Nguyen, L. T., \& Dang, L. D. 2012. Biodegradation of phenol by native bacteria isolated from dioxin contaminated soils. Journal Bioremediation and Biodegradation 3: 168.

Cai, W., Li, J., \& Zhang, Z. 2007. The characteristics and mechanisms of phenol biodegradation by Fusarium sp. Journal of Hazardous Materials 148: 38-42.

Chen, K. N., Chen, M. J., \& Lin, C. W. 2006. Optimal combination of the encapsulating materials for probiotic mircocapsules and its experimental verification (R1). Journal of Food Engineering 76: 313-3.

El-Naas, M. H., Muhtaseb, S. A. A., \& Makhlouf, S. 2009. Biodegadation of phenol by Pseudomonas putida immobilized in polyvinyl alcohol (PVA) gel. Journal of Hazardous Materials 164: 720-725.

Gami, A. A., Shukor, M. Y., Khalil, K. A., Dahalan, F. A., Khalid, 
A., \& Ahmad, S. A. 2014. Phenol and phenolic compounds toxicity. Journal of Environmental Microbiology and Toxicology 2(1): 11-23.

Haiyin, X., Thomas, M., Chen, S., Cimeglia, C. E., \& Ceh, H. 2007. Anaerobic metabolism of 1-amino-2-naphthol-based azo dyes (Sudan dyes) by human intestinal microflora. Applied Environmental Microbiology 73: 7759-7762.

Hasan, S. A., \& Jabeen, S. 2015. Degradation kinetics and pathway of phenol by Pseudomonas and Bacillus species. Biotechnology and Biotechnology Equipment 29(1): 45-53.

Haynes, W. 2013. Tukey's Test. In: Dubitzky, W., Wolkenhauer, O., Cho, K.H., Yokota, H. (eds) Encyclopedia of Systems Biology. Springer, New York, NY.

Health Protection Agency (HPA). 2007. Phenol: General information. Health Protection Agency. London.

Javed, M., \& Usmani, N. 2015. Stress response of biomolecules (carbohydrate, protein and lipid profiles) in fish Channa punctatus inhabiting river polluted by Thermal Power Plant effluent. Saudi Journal of Biological Sciences 22: 237-242.

Khleifat, K. M. 2006. Biodegradation of phenol by Ewingella americana: Effect of carbon starvation and some growth conditions. Process Biochemistry 41: 2010-2016.

Leitão, A. L. 2009. Potential of Penicillium species in the bioremediation field. International Journal of Environmental Research and Public Health 6(4): 1393-1417.

Leitão, A. L., Duarte, M. P., \& Oliveira, J. S. 2007. Degradation of phenol by a halotolerant strain of Penicillium chrysogenum. International Biodeterioration and Biodegradation 59: 220-225.

Mahiuddin, Md., Fakhruddin, A. N. M., \& Abdullah-Al-Mahin. 2012. Degradation of phenol via meta cleavage pathway by Pseudomonas fluorescens PU1. International Scholarly Research Network 2012: 1-6.

Mendonça, E., Martins, A., \& Anselmo, A. M. 2004. Biodegradation of natural phenolic compounds as single and mixed substrates by Fusarium flocciferum. Electronic Journal of Biotechnology 7(1): 30-37.

Michalowicz, J. \& Duda, W. 2007. Phenols - sources and toxicity: Review. Polish Journal of Environment Study 16(3): 347-362.

Neumann, G., Teras, R., Manson, L., Kivisaar M., Schayer, F., \& Heipieper, H. J. 2004. Simultaneous degradation of atrazine and phenol by Pseudomonas sp. strain ADP: Effect of toxicity and adaptation. Applied and Environmental Microbiology 70(4): 1907-1912.

Panagos, P., Liedekerke, M. V., Yigini, Y., \& Montanarella, L. 2013. Contaminated sites in europe: Review of the current situation based on data collected through a european network. Journal of Environmental and Public Health 2013: 1-11.

Pryce, T. M., Palladino, S., Price, D. M., Gardam, D. J., Campbell, P. B., Christiansen, K. J., \& Murray, R. J. 2006. Rapid identification of fungal pathogens in BacT/ALERT, BACTEC and BBL MGIT media using polymerase chain reaction and DNA sequencing of the internal transcribed spacer regions. Diagnostic Microbiology and Infectious Disease 54: 289-297.

Raeder, U. \& Broda, P. 1985. Rapid preparation of DNA from filamentous fungi. Letters in Applied Microbiology 1: 17-20.

Ravikumar, S., Parimala, P. S., \& Gokulakrishnan, R. 2011. Biodegradation of phenolic compounds by using halotolerant microbes. International Journal of Plant, Animal and Environmental Sciences 1(2): 38-45.

Rittmann, B. E. \& McCarty, P. L. 2001. Environmental Biotechnology: Principles and Applications, New York.

Santos, V. L. \& Linardi, R. 2004. Biodegradation of phenol by a filamentous fungi isolated from industrial effluents identification and degradation potential. Process Biochemistry 39: 1001-1006.

Sarwade, V. D. \& Gawai, K. R. 2014. Biodegradation of phenol by alkaliphiic Bacillus badius D1. Journal of Environmental Science,
Toxicology and Food technology 8(5): 28-35.

Soudi, M. R. \& Kolahchi. N. 2011. Bioremediation potential of a phenol degrading bacterium, Rhodococcus erythropolis SKO-1. Progress in Biological Sciences 1: 31-40.

Sridevi, V., Chandana Lakshmi, M. V. V., Adimadhyam, S. V. N., \& Mdicherla, N. R. 2011. Statistical optimization of process variables by Response Surface Methodology to enhance phenol degradation by Pseudomonas putida (NCIM 2012). Advances in Bioscience and Biotechnology 2: 175-181.

Sridevi, V., Chandana Lakshmi, M. V. V., Manasa, M., \& Sravani, M. 2012. Metabolic pathways for the biodegradation of phenol. International Journal of Engineering Science and Advanced Technology 2(3): 695-705.

Stoilova, I., Krastanov, A., \& Bui, H. 2008. Biodegradation of mixed phenolic compounds by a microbial association of Aspergillus awamori and Thermoascus aurantiacus. Electronic Journal of Environmental, Agricultural and Food Chemistry 7: 2625-2633.

Stoilova, I., Krastanov, A., Stanchev, V., Daniel, D., Gerginova, M, \& Alexieva, Z. 2006. Biodegradation of high amounts of phenol, catechol, 2,4-dichlorophenol and 2,6dimethoxyphenol by Aspergillus awamori cells. Ensyme and Microbial Technology 39: 1036-1041.

Supriya, C. H. \& Neehar, D. 2014. Biodegradation of phenol by Aspergillus niger. Journal of Pharmacy 4(7): 11-17.

Thappu, B., Ajay Kumar, K. C., \& Ghimire, A. 2012. A review on biodegradation of petroleum hydrocarbon contaminated soil. Kathmandu University Journal of Science, Engineering and Technology 8(1): 164-170.

Tuah, P. M., Rashid, N. A. A., \& Salleh M. M. 2009. Degradation pathway of phenol through ortho-cleavage by Candida tropicalis RETL-Cr1. Borneo Science 1-8.

Van Schie, P. M. \& Young, L. Y. 2000. Biodegradation of phenol: Mechanisms and applications. Bioremediation Journal 4: 1-18.

Visagie, C. M., Houbraken, J., Frisvad, J. C., Hong, S. B., Klaassen, C. H. W., Perrone, G., Seifert, K. A., Varga, J., Yaguchi, T., \& Samson, R. A. 2014. Identification and nomenclature of the genus Penicillium. Studies in Mycology 78: 343-31.

Wang, L., Li, Y., Yu, P., Xie, Z., Luo, Y., \& Lin, Y. 2010. Biodegradation of phenol at high concentration by a novel fungal strain Paecilomyces variotii JH6. Journal of Hazardous Materials 183: 366-371.

White, T. J., Burns, T., Lee, S., \& Taylor, J. 1990. Amplification and direct sequencing of fungal ribosomal RNA genes for phylogenetics. In: Innis, M.A., Gefland, D.H ., Sninsky, J. J. and White, T.J. (Eds.). PCR Protocols: A Guide to Methods and Application. Academic Press. San Diego, CA. pp 315-322. 